\title{
High Application Rates of Reclaimed Water Benefit Citrus Tree Growth and Fruit Production
}

\author{
Lawrence R. Parsons ${ }^{1}$, T. Adair Wheaton ${ }^{1}$, and William S. Castle ${ }^{1}$ \\ University of Florida, Institute of Food and Agricultural Sciences, Citrus \\ Research and Education Center, 700 Experiment Station Road, Lake Alfred, \\ FL 33850-2299
}

Additional index words. orange, tangelo, wastewater, irrigation, effluent, rootstock, Citrus sinensis

\begin{abstract}
Conversion of wastewater to reclaimed water for crop irrigation conserves water and is an effective way to handle a growing urban problem: the disposal of wastewater. Water Conserv II is a large reclaimed water project developed by Orlando and Orange County, Fla., that presently irrigates $\approx 1900$ ha of citrus. The project includes a research component to evaluate the response of citrus to irrigation using reclaimed water. Citrus trees in an experimental planting responded well to very high application rates of reclaimed water. Irrigation treatments included annual applications of $400 \mathrm{~mm}$ of well water, and 400,1250 , and $2500 \mathrm{~mm}$ of reclaimed water. The $2500-\mathrm{mm}$ rate is excessive, and since disposal was of interest, this rate was used to determine if citrus could tolerate such high rates of irrigation. The effects of these treatments were compared on 'Hamlin' orange [Citrus sinensis (L.) Osb.] and 'Orlando' tangelo (C. paradisi Macf. x C. reticulata Blanco) combined with four rootstocks: Carrizo citrange [Citrus sinensis (L.) Osb. $x$ Poncirus trifoliata (L.) Raf.], Cleopatra mandarin (C. reticulata Blanco), sour orange (C. aurantium L.), and Swingle citrumelo (C. paradisi $x$ P. trifoliata). Growth and fruit production were greatest at the highest irrigation rate. Concentration of soluble solids in the juice was usually lowered by the highest irrigation rate, but total soluble solids per hectare were $15.5 \%$ higher compared to the $400-\mathrm{mm}$ rate, due to the greater fruit production. While fruit soluble solids were usually lowered by higher irrigation, the reduction in fruit soluble solids observed on three of the rootstocks did not occur in trees on Carrizo citrange. Fruit peel color score was lower but juice color score was higher at the highest irrigation rate. Crop efficiency (fruit production per unit of canopy volume) was usually lower at the 2500$\mathrm{mm}$ rate and declined as trees grew older. Weed cover increased with increasing irrigation rate, but was controllable. Irrigation with high rates of reclaimed water provided a satisfactory disposal method for treated effluent, benefited growth and production of citrus, and eliminated the need for other sources of irrigation water. Reclaimed water, once believed to be a disposal problem in Florida, is now considered to be one way to meet irrigation demands.
\end{abstract}

Sewage wastewater or effluent is often viewed as a disposal problem, but it can be a source of reclaimed water for irrigation. This approach creates an alternative disposal method for a waste treatment facility, may benefit agriculture as a source of irrigation water, and reduces the demand for use of surface or ground water for irrigation. Potential disadvantages of using reclaimed water for agricultural irrigation include real or perceived concerns about water quality, such as viruses, diseases, heavy metals, and the safety of crops for human consumption (Parsons and Wheaton, 1996; Parsons et al., 1995). Other disadvantages include the possible requirement to use more water than is needed for irrigation or to use it during rainy periods when it is not needed.

\footnotetext{
Received for publication 27 Sept. 2000. Accepted for publication 27 Apr. 2001. Florida Agricultural Experiment Station Journal Series No. R-07798. We would like to thank M. Cody, K. Morgan, and A. Fares for their assistance. ${ }^{1}$ Professor.
}

In some arid regions where freshwater supplies are limited, irrigation with reclaimed water is already commonly practiced (Feigin et al., 1991). In humid regions such as Florida, wastewater had been considered to be a disposal problem, but has recently become regarded as a potential source of reclaimed water for irrigation. Reclaimed water has been used for irrigation of a number of crops, including forage crops, turfgrass, golf courses, and woody perennials for biomass production (Pettygrove and Asano, 1985). It has been used successfully for irrigation of fruit trees (Basiouny, 1982) and has increased trunk diameter growth, fruit number, and yield of apples (Neilsen et al., 1989).

In an observational survey where irrigation application rates were unknown, no adverse effects of reclaimed water irrigation were seen in Florida citrus groves (Zekri and Koo, 1993). In Spain, Lapena et al. (1996) found that irrigation of citrus trees with reclaimed water was not harmful. Maurer et al. (1995) showed that grapefruit yield in Florida increased at reclaimed water irrigation rates of 23.1 and
$30.7 \mathrm{~mm} /$ week, but application rates $>30.7$ $\mathrm{mm} /$ week decreased yields in poorly drained Spodosols. In another study, irrigation rate did not affect young grapefruit tree growth (Maurer and Davies, 1993).

In order to deal with wastewater disposal, the City of Orlando and Orange County began a project called Water Conserv II. The goal of this project was to dispose of urban wastewater by converting it to reclaimed water and using the water for citrus, ornamental, and golf course irrigation. Since the city and county wanted to dispose of the wastewater, there was interest in determining if large volumes of this water could be applied to citrus groves without causing damage to trees. Contracts were set up with growers who agreed to accept either 625 or $1250 \mathrm{~mm}$ of reclaimed water per year. Water Conserv II presently irrigates $\approx 1900$ ha of citrus and has become one of the largest reclaimed water agricultural irrigation projects of its type in the United States. It is the first project in Florida to be permitted to irrigate crops for human consumption with reclaimed water (McMahon et al., 1989).

The objective of this research was to determine the effects of irrigation with reclaimed water on two citrus cultivars and four rootstocks. Treatments included commonly used irrigation rates as well as excessively high application rates to determine the capacity of a citrus grove to act as a disposal site for reclaimed water.

\section{Materials and Methods}

Experiment site. The experiment was located near the Water Conserv II distribution center west of Orlando, Fla. (lat. $28^{\circ} 28^{\prime} 20^{\prime \prime} \mathrm{N}$, long. $81^{\circ} 38^{\prime} 50^{\prime \prime} \mathrm{W}$, elevation $64 \mathrm{~m}$ ). This is an area where citrus has been traditionally grown, but it is subject to periodic damaging freezes. The soil is an excessively drained Candler fine sand (hyperthermic, uncoated Typic Quartzipsamments). It has very low waterholding capacity (available water $<0.06$ $\mathrm{cm} \cdot \mathrm{cm}^{-1}$ with $<1 \%$ organic matter and $<3 \%$ clay. The majority of citrus tree roots are in the top $90 \mathrm{~cm}$, but some roots can extend to depths below $1.5 \mathrm{~m}$ (Menocal-Barberena, 1999).

Reclaimed water. The reclaimed water used in this study was provided through the Water Conserv II project. This water is normal sewage effluent collected from the City of Orlando and surrounding communities and treated with advanced secondary treatment with highlevel disinfection, coagulation, filtration, and chlorination. Water quality standards were established in negotiations between Water Conserv II, Univ. of Florida researchers, and growers to ensure that water would be suitable for citrus irrigation. This reclaimed water meets drinking water standards for a number of elements (Table 1), has no color or odor, and is very low in heavy metals. While this water is suitable for irrigation (Ayers and Westcot, 1976), it was not known how trees would respond to the high application rates that the city desired for disposal.

Experimental design. 'Hamlin' sweet orange and 'Orlando' tangelo trees in combina- 
tion with four rootstocks were obtained from commercial nurseries and planted at a $3.0 \times 6.1$ $\mathrm{m}$ spacing in Fall 1987. They were planted in a split-split plot arrangement with four replications of 24-tree plots ( six trees in four adjacent rows). Irrigation treatments consisted of annual applications of well or reclaimed water at $400 \mathrm{~mm}$ (W400, RW400), and reclaimed water at 1250 and $2500 \mathrm{~mm}$ (RW1250, RW2500). Each irrigation main plot was subdivided into plots with the two scion cultivars, which were further divided into plots assigned to the four rootstocks (Table 2).

All data were analyzed using the SASGLM split plot model of the analysis of variance. Annual fruit quality measurements for the 400- and 2500-mm treatments were averaged over the 5-year period from 1993 through 1997. This time period was chosen because trees were representative of mature trees in Florida.

Cultural practices and measurements. Trees were irrigated with $360^{\circ}$ microsprinklers that delivered $\approx 57 \mathrm{~L} \cdot \mathrm{h}^{-1}$ and covered $\approx 80 \%$ of the land area. The differential irrigation treatments were begun on 1 Oct. 1989. The 400$\mathrm{mm}$ rate is near the recommended rate and is commonly used for Florida citrus. The 1250$\mathrm{mm}$ rate is the maximum amount growers on the Water Conserv II project were expected to use, and $2500 \mathrm{~mm}$ is a very high rate that could be potentially damaging to citrus. From 1989 to 1992 , all treatments were irrigated every second or third day regardless of rainfall. Beginning in 1993, scheduling of the W400 and RW400 treatments was changed to maintain soil-available water above one-third depletion in the spring and above two-thirds depletion during the rest of the year. Depending on rainfall, annual rates for the $400-\mathrm{mm}$ treatments varied from 400 to $550 \mathrm{~mm}$. Evapotranspiration (ET) was estimated from data collected by a weather station at the site. Rainfall was measured, daily ET was calculated, and a water budget system was used to determine irrigation. Trees were irrigated every 2 to $3 \mathrm{~d}$ in the spring and every 4 to $10 \mathrm{~d}$ from July to January. The 1250-mm treatment (Table 2) was discontinued in 1993 to allow for another study. The $2500-\mathrm{mm}$ rate continued to be irrigated every second day. Annual rainfall ranged from 983 to $1790 \mathrm{~mm}$.

Complete fertilizer was applied to all treatments at the recommended rate of $\mathrm{N}$ at 224 $\mathrm{kg} \cdot \mathrm{ha}^{-1}$ per year in split applications (Tucker et al., 1995). Because $\mathrm{N}$ fertilizer was applied in adequate amounts, the nutritional value of reclaimed water was not considered as a factor in this study. Because differences in weed growth among irrigation treatments were observed, two independent observers visually estimated weed cover of the herbicide strips in the summer and their estimate of percent weed cover was averaged.

Tree growth was initially determined by measuring trunk diameter annually and later by calculating canopy volume. Trunk diameter measurements were made $\approx 10 \mathrm{~cm}$ above the bud union on a smooth section of the trunk. Canopy volume was calculated from measurements of canopy height and diameters

Table 1. Florida drinking water standards, typical well water values, Conserv II maximum average concentration limits (MACL), and typical values in Conserv II water. All values are in $\mathrm{mg} \cdot \mathrm{L}^{-1}$ except for $\mathrm{pH}, \mathrm{EC}$, and SAR.

\begin{tabular}{lcccc}
\hline \hline & $\begin{array}{c}\text { Drinking water } \\
\text { max. contam. level } \\
\left(\mathrm{mg} \cdot \mathrm{L}^{-1}\right)\end{array}$ & $\begin{array}{c}\text { Well water } \\
\text { typical values } \\
\left(\mathrm{mg} \cdot \mathrm{L}^{-1}\right)\end{array}$ & $\begin{array}{c}\text { Conserv II water } \\
\text { MACL } \\
\left(\mathrm{mg} \cdot \mathrm{L}^{-1}\right)\end{array}$ & $\begin{array}{c}\text { Conserv II water } \\
\text { typical values } \\
\left(\mathrm{mg} \cdot \mathrm{L}^{-1}\right)\end{array}$ \\
\hline Arsenic & 0.05 & --- & 0.10 & $<0.005$ \\
Barium & 2 & --- & 1 & $<0.01$ \\
Beryllium & 0.004 & --- & 0.1 & $<0.003$ \\
Bicarbonate & --- & -- & 200 & 105 \\
Boron & -- & 0.02 & 1.0 & $<0.25$ \\
Cadmium & 0.005 & --- & 0.01 & $<0.002$ \\
Calcium & --- & 39 & 200 & 42 \\
Chloride & 250 & 15 & 100 & $75-81$ \\
Chromium & 0.1 & ---0.005 & $<0.005$ \\
Copper & 1 & 360 & 0.01 & $0.002-0.05$ \\
EC (umhos & 781 & 0.02 & 1100 & 720 \\
Iron & 0.3 & --- & 5.0 & $0.01-0.37$ \\
Lead & 0.015 & 16 & 0.1 & $<0.003$ \\
Magnesium & --- & 0.01 & 25 & 8.5 \\
Manganese & 0.05 & --- & 0.20 & $0.006-0.042$ \\
Mercury & 0.002 & -- & 0.01 & $<0.0002$ \\
Nickel & 0.1 & 3 & 0.2 & 0.01 \\
Nitrate-N & 10 & 7.8 & 10 & $6.1-7$ \\
pH & $6.5-8.5$ & 0.01 & $6.5-8.4$ & $7.1-7.2$ \\
Phosphorous & --- & 6 & 10 & 1.1 \\
Potassium & -- & 0.6 & 30 & 11.5 \\
SAR & --- & --- & --- & 2.5 \\
Selenium & 0.05 & -- & 0.02 & $<0.002$ \\
Silver & 0.1 & 18 & 0.05 & $<0.003$ \\
Sodium & 160 & 23 & 70 & $50-70$ \\
Sulfate & 250 & 0.02 & 100 & $29-55$ \\
Zinc & 5 & & 1.0 & $0.04-0.06$ \\
\hline & & & &
\end{tabular}

Table. 2. Treatments applied to the main plots in the reclaimed water experiment. ${ }^{\mathrm{z}}$

\begin{tabular}{llll}
\hline & & \multicolumn{2}{c}{ Irrigation schedule } \\
\cline { 3 - 4 } Irrigation treatment & \multicolumn{1}{c}{ Irrigation rate } & 1989-92 & \multicolumn{1}{c}{$1993-97$} \\
\hline W400 & Well water $400 \mathrm{~mm}$ & Every 3rd day & Irrigate at 1/3 or 2/3 depletion \\
RW400 & Reclaimed water $400 \mathrm{~mm}$ & Every 3rd day & Irrigate at $1 / 3$ or 2/3 depletion \\
RW1250 & Reclaimed water $1250 \mathrm{~mm}$ & Every 2nd day & Discontinued \\
RW2500 & Reclaimed water $2500 \mathrm{~mm}$ & Every 2nd day & Every 2nd day
\end{tabular}

Scion-Sub-plot

Hamlin orange Citrus sinensis L. Osb.

Orlando tangelo Citrus paradisi Macf. x C. reticulata Blanco

Rootstock-Sub-sub-plot

Carrizo citrange Citrus sinensis (L.) Osbeck x Poncirus trifoliata (L.) Raf.

Cleopatra mandarin $C$. reticulata Blanco

Sour orange $C$. aurantium $\mathrm{L}$.

Swingle citrumelo $C$. paradisi $\times$ P. trifoliata

${ }^{\mathrm{x}}$ The factorial experiment was arranged in a split-split-plot design with four replications. Differential irrigation treatments were begun 1 Oct. 1989 and were designed to apply $\approx 400,1250$, or $2500 \mathrm{~mm}$ of water annually in equal increments throughout the year. Beginning in 1993, scheduling of the 400-mm rate was adjusted to maintain soil available water above one-third depletion in the spring (irrigation every $2-3 \mathrm{~d}$ ) and above two-thirds depletion during the rest of the year (irrigation every 4-10 d). The 1250-mm treatment was discontinued at that time.

${ }^{y}$ See text for details.

(Wheaton et al., 1995). Yield was measured in the autumn when fruit were mature by harvesting two representative trees in each plot. Crop efficiency was estimated by dividing the weight of the fruit per tree by the canopy volume. Fruit samples were collected at the time of harvest each year to determine the treatment effects on fruit and juice quality. Juice was extracted using standardized automatic extraction machinery and analyzed for soluble solids and acid concentration with computerized test equipment found in Florida processing plants. External fruit color was measured with a HunterLab Color Difference Meter (HunterLab, Fairfax, Va.) and reported as the $\mathrm{a} / \mathrm{b}$ ratio, which is negative for green fruit, close to zero for yellow fruit, and increases in positive value with improving orange color (Wheaton and Stewart, 1973). Juice color was determined using a citrus colorimeter.

\section{Results}

Trees in all treatments grew and produced well, but treatment effects on tree size, yield, fruit quality, and weed cover were observed. Some irrigation effects were due to the method of scheduling during the first years of the experiment. Irrigation was initially scheduled in equal increments throughout the year because the production of reclaimed water is relatively constant during the year and be- 
cause the grower contracts called for water use throughout the year. This method of scheduling provided adequate water at the 1250 - and 2500-mm rates, but was a limiting factor in growth at the $400-\mathrm{mm}$ rate. Scheduling of the 400-mm treatments was changed in 1993 to maintain soil water above one-third depletion during flowering and fruit set (February through June), and above two-thirds depletion for the rest of the year. Because of variable rainfall in Florida, irrigation based on this water budget method is usually superior to a strict calendar method.

Tree size. The higher irrigation rates promoted greater trunk and canopy growth (Fig.1). In the first 3 years, trunk diameters were similar for the well water and reclaimed water treatments at the $400-\mathrm{mm}$ rate. From years 4 to 10 , trees that received the 1250 - and 2500-mm per year application rates were significantly larger than those receiving the 400 -mm treatments (Figs. 1, 2).

Yield and fruit quality. Because these cultivars represent examples of fresh-market ('Orlando') and processed ('Hamlin') fruit, yield data are expressed both in terms of tons per hectare and tons soluble solids per hectare. Soluble solids are an important indicator of processing yield. In addition to promoting greater canopy size, the higher irrigation rates promoted significantly greater fruit production (Table 3). For the 5-year average from 1993 to 1997 , the $2500-\mathrm{mm}$ reclaimed water rate produced $19.3 \%$ more tons per hectare than the 400-mm reclaimed water treatment.

Fruit quality variables were averaged over 5 years and are shown in Table 3 . The high irrigation rate caused significant reduction in juice soluble solids concentration during this period. Even though the high irrigation rate caused a significant reduction in juice soluble solids, total soluble solids per hectare were higher at the 2500 - $\mathrm{mm}$ irrigation rate because of the greater fruit production. The greater yield compensated for the soluble solids dilution effect caused by the high irrigation rate, and the $2500-\mathrm{mm}$ rate produced $15.5 \%$ more soluble solids/hectare than the $400-\mathrm{mm}$ reclaimed water treatment.

There were several significant interactions in total yield and fruit soluble solids between scion and irrigation and between rootstock and irrigation. The response of fruit soluble solids yield ( $\left.\mathrm{t} \cdot \mathrm{ha}^{-1}\right)$ to irrigation treatment was greater for 'Orlando' tangelo than for 'Hamlin' orange (Fig. 3). While fruit soluble solids were usually decreased by higher irrigation, the reduction in fruit soluble solids due to the high irrigation rate observed on three of the rootstocks did not occur for trees on Carrizo citrange (Fig. 4).

Crop efficiency generally declined as trees got older (Fig. 5). Because the high irrigation rate promoted rapid canopy vegetative growth, trees at the $2500-\mathrm{mm}$ rate had significantly lower crop efficiency in years 6 and 7 (Fig. 5).

Excessive weed growth was associated with the higher irrigation rates and was observed for several years (Fig. 6). Nevertheless, weed growth was manageable with mowing and herbicide use.

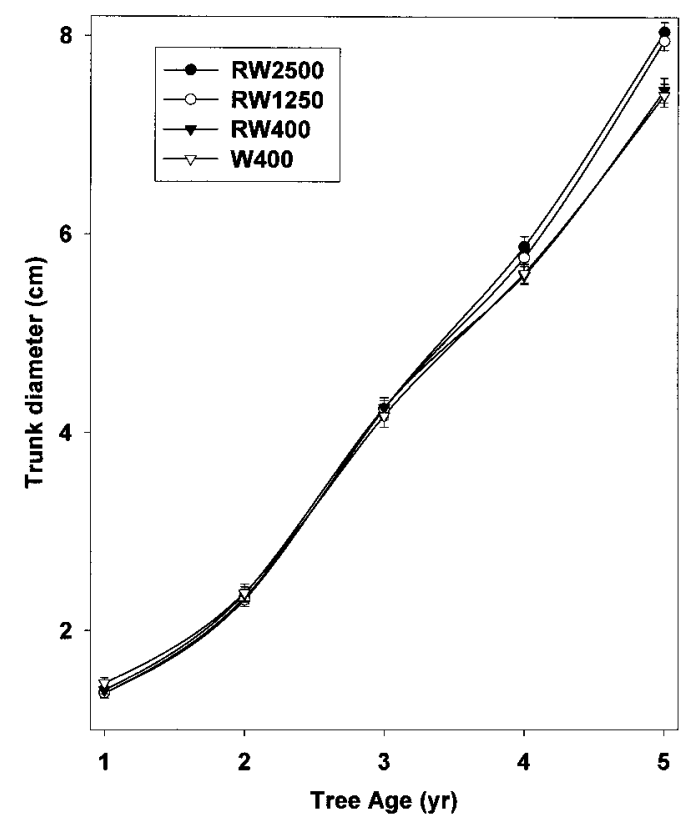

Fig. 1. Irrigation effects on trunk diameter growth. Data are averaged over both scions and all rootstocks, mean and standard error.

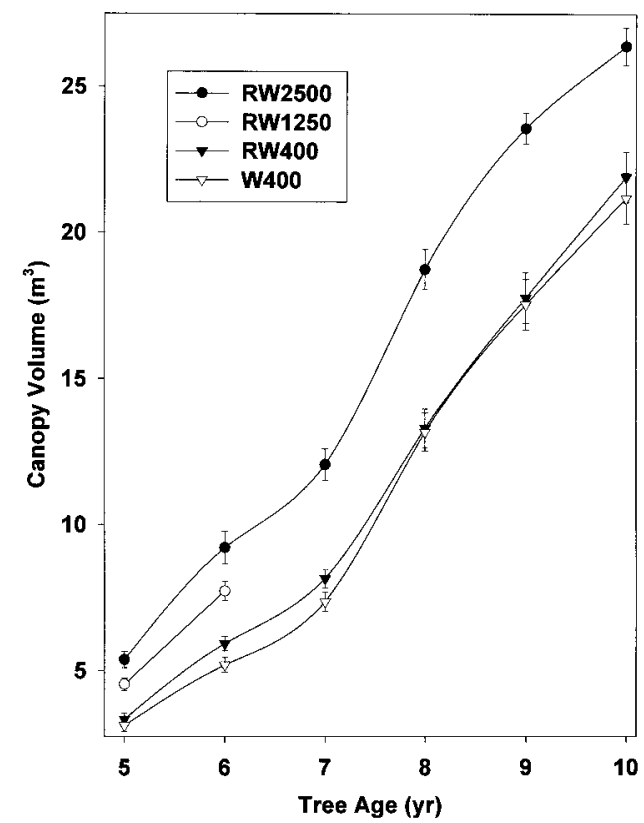

Fig. 2. Irrigation effects on canopy volume. Data are averaged over both scions and all rootstocks, mean and standard error.

Table 3. Average fruit quality for 1993-97 and canopy volume for 1997 (Year 10).

\begin{tabular}{|c|c|c|c|c|c|c|c|c|c|c|c|}
\hline & Fruit & Juice & Juice & Juice & Solids: & $\begin{array}{c}\text { Fruit } \\
\mathrm{SS}^{\mathrm{z}}\end{array}$ & \multicolumn{2}{|c|}{ Yield } & \multirow{2}{*}{$\begin{array}{l}\text { Fruit } \\
\text { color } \\
\mathrm{a} / \mathrm{b}^{\mathrm{y}}\end{array}$} & \multirow{2}{*}{$\begin{array}{c}\text { Juice } \\
\text { color } \\
\text { no. }\end{array}$} & \multirow{2}{*}{$\begin{array}{c}\text { Canopy } \\
\text { vol } \\
\mathrm{m}^{3} / \text { tree }\end{array}$} \\
\hline & $\begin{array}{l}\text { size } \\
\text { g/fruit }\end{array}$ & $\begin{array}{c}\text { content } \\
\%\end{array}$ & $\begin{array}{c}\mathrm{SS}^{\mathrm{z}} \\
\%\end{array}$ & $\begin{array}{c}\text { acid } \\
\%\end{array}$ & $\begin{array}{l}\text { acid } \\
\text { ratio }\end{array}$ & $\begin{array}{l}\mathrm{g} \cdot \mathrm{kg}^{-1} \\
\text { fruit }\end{array}$ & $\mathrm{t} \cdot \mathrm{ha}^{-1}$ & $\begin{array}{c}\mathrm{SS}^{\mathrm{z}} \\
\mathrm{t} \cdot \mathrm{ha}^{-1}\end{array}$ & & & \\
\hline Irrigation & & & & & & & & & & & $\underline{\text { Year } 10}$ \\
\hline Well 400 & 189.0 & 62.3 & 10.71 & 0.69 & 15.86 & 66.58 & 56.64 & 3.74 & 0.518 & 35.6 & 12.89 \\
\hline Reclaimed 400 & 193.1 & 62.7 & 10.67 & 0.71 & 15.33 & 66.74 & 62.87 & 4.18 & 0.513 & 35.7 & 13.41 \\
\hline Reclaimed 2500 & 189.4 & 62.7 & 10.29 & 0.68 & 15.51 & 64.39 & 75.02 & 4.82 & 0.456 & 35.8 & 17.99 \\
\hline $\mathrm{I}^{\mathrm{x}}$ & & & $* *$ & $*$ & $*$ & $*$ & $* * *$ & $* * *$ & $* *$ & $* *$ & $* * *$ \\
\hline $\mathrm{I} \times \mathrm{S}$ & & & & & & & $*$ & $* *$ & & & \\
\hline $\mathrm{I} \times \mathrm{R}$ & & & $* *$ & & & $* *$ & & & & & \\
\hline 400 vs. 2500 & & & $* *$ & $*$ & & & $* * *$ & $* * *$ & $* *$ & $* * *$ & $* *$ \\
\hline
\end{tabular}

${ }_{\mathrm{z} S}=$ soluble solids.

$\mathrm{y} \mathrm{a} / \mathrm{b}$ is a color index that increases as external fruit color improves.

${ }^{x}$ Statistics from SAS Proc GLM include contrast statements for the indicated comparisons; $I=$ irrigation; $S$ $=$ scion $; \mathrm{R}=$ rootstock

${ }^{*},{ }^{* *}, * * *$ Significant at $P \leq 0.05,0.01$, or 0.001 , respectively. 


\section{Discussion}

These results show that irrigation with excessively high rates of reclaimed water was not detrimental to canopy growth and fruit production. This was due to the good drainage of this sandy soil and the lack of root diseases. The slight reduction in juice soluble solids at the high irrigation rate was more than compensated for by the higher total soluble solids $\left(\mathrm{t} \cdot \mathrm{ha}^{-1}\right)$ yield. Koo and Zekri (1989) reported a decrease in fruit soluble solids in groves using reclaimed water at rates higher than other groves using well water, and this agrees with our results.

Fresh fruit production also benefited from the high irrigation levels. The increased yield $\left(\mathrm{t} \cdot \mathrm{ha}^{-1}\right)$ was desirable, but external fruit color was poorer at the high irrigation rate.

Weed cover was increased at the high irrigation rate, but this was manageable. When using higher irrigation rates with reclaimed water rather than well water, greater weed growth was also seen in growers' fields (Zekri and Koo, 1993).

While the 2500-mm rate promoted canopy growth by reducing water stress, it could cause leaching of chemicals and fertilizer elements such as nitrate. Even though this reclaimed water meets drinking water standards for nitrate, the high irrigation rate could leach applied nitrogen fertilizers. This high rate would also cause more potential herbicide leaching and/or use. Normal annual ET for citrus in this area is $\approx 1210 \mathrm{~mm}$; hence, $2500 \mathrm{~mm}$ of irrigation would cause leaching.

The yield increase was largely due to increased canopy growth. Irrigation requirements for crop production vary with season, weather, and crop evapotranspiration. Reclaimed water, however, is produced on a relatively constant basis. Since a major goal of this research involved disposal of reclaimed water, irrigation was scheduled on a constant basis throughout the year to apply the desired amount of water. Because water was applied equally throughout the year, the 400-mm rate did not supply adequate water during periods of high ET and low rainfall. Thus, applying the same volume of water, but scheduling it based on weather and crop need, could possibly have improved the growth and production of these trees. During the 1993-97 period, the improved irrigation scheduling reduced the water deficit experienced earlier in the 400-mm treatments.

To deal with the city's desire for regularly scheduled irrigation and the growers' desire for water use as needed, alternate disposal sites for the reclaimed water needed to be provided. This has been done with the construction of Rapid Infiltration Basins (RIBs) or large percolation ponds, which allow greater scheduling flexibility for the growers.

There was initial concern that high irrigation rates might cause flooding damage or promote foot rot or damage to feeder roots. On these well-drained soils, no symptoms of flooding damage were seen. During this time, there was little evidence of foot rot caused by

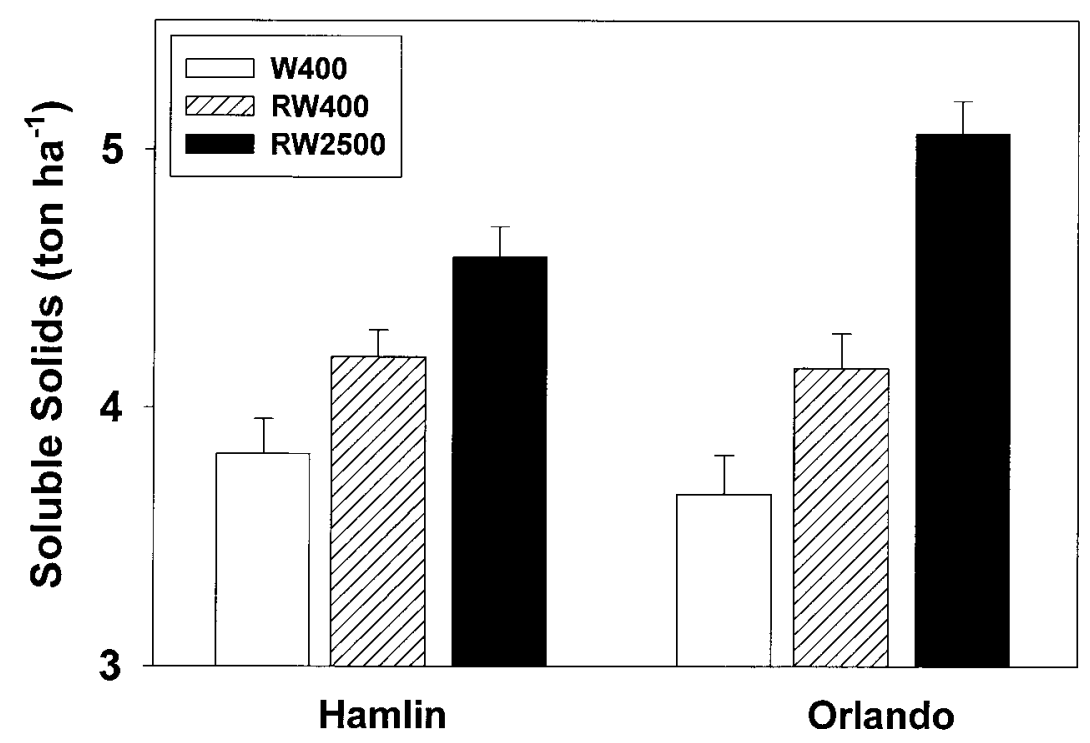

Fig 3. Significant interaction involving irrigation based on 5-year average yield and fruit quality. The response of fruit soluble solids/ha to irrigation treatment was greater for 'Orlando' tangelo than for 'Hamlin' orange.

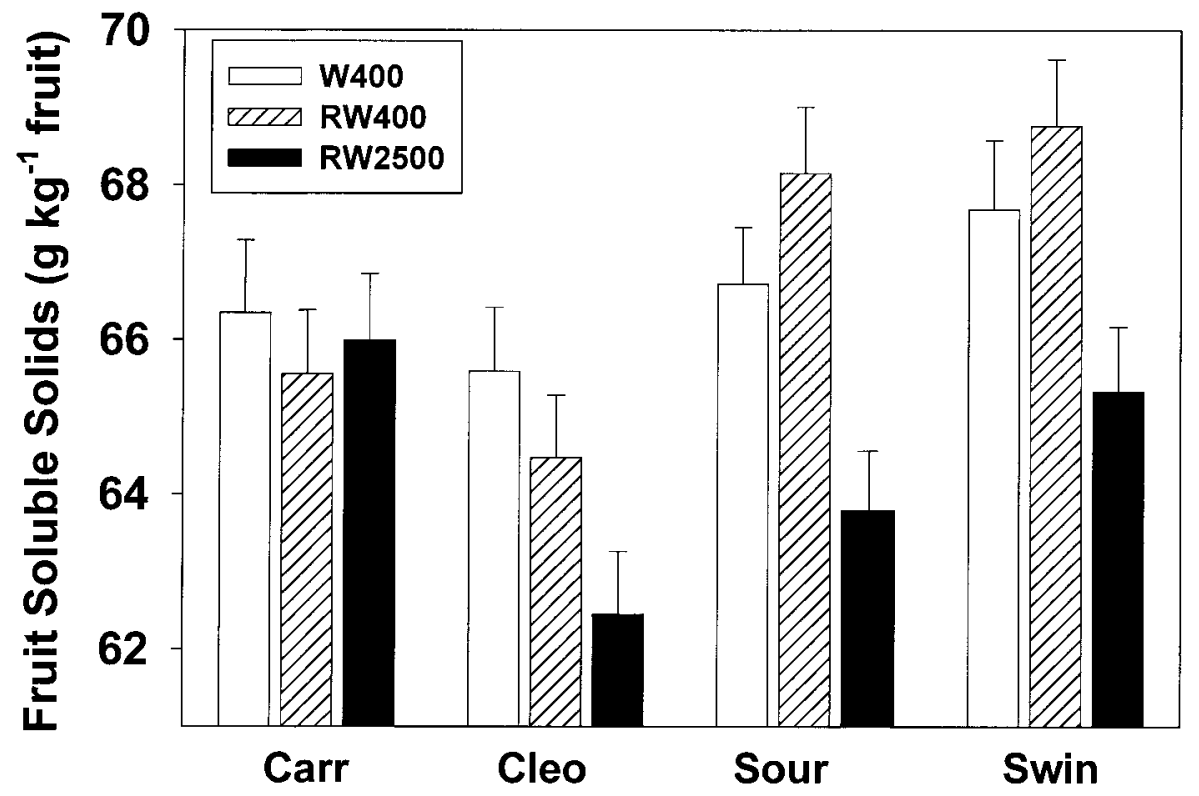

Fig. 4. Significant interaction involving irrigation based on 5-year average yield and fruit quality. The reduction in soluble solids due to the high irrigation rate on several rootstocks did not occur for trees on Carrizo citrange rootstock.

Phytophthora in this planting (Timmer, personal communication).

The increased yields and total solids production at these excessively high irrigation rates were surprising and unexpected. The disease and flooding problems that were expected did not appear.

This study shows that very high rates of reclaimed water can be applied successfully to citrus on well-drained soils. There are benefits to the urban population, the agricultural community, and the environment. The urban sector benefits by disposing of large quantities of wastewater. The agricultural community ben- efits by getting a free or low-cost reliable water supply. The environment benefits because pumping for agricultural irrigation does not lower groundwater levels, and reclaimed water application can enhance groundwater recharge.

\section{Literature Cited}

Ayers, R.S. and D.W. Westcot. 1976. Water quality for agriculture. Irr. Drainage Paper 29. FAO. Rome.

Basiouny, F.M. 1982. Wastewater irrigation of fruit trees. BioCycle 23:51-53.

Feigin, A., I. Ravina, and J. Shalhevet. 1991. Irriga- 


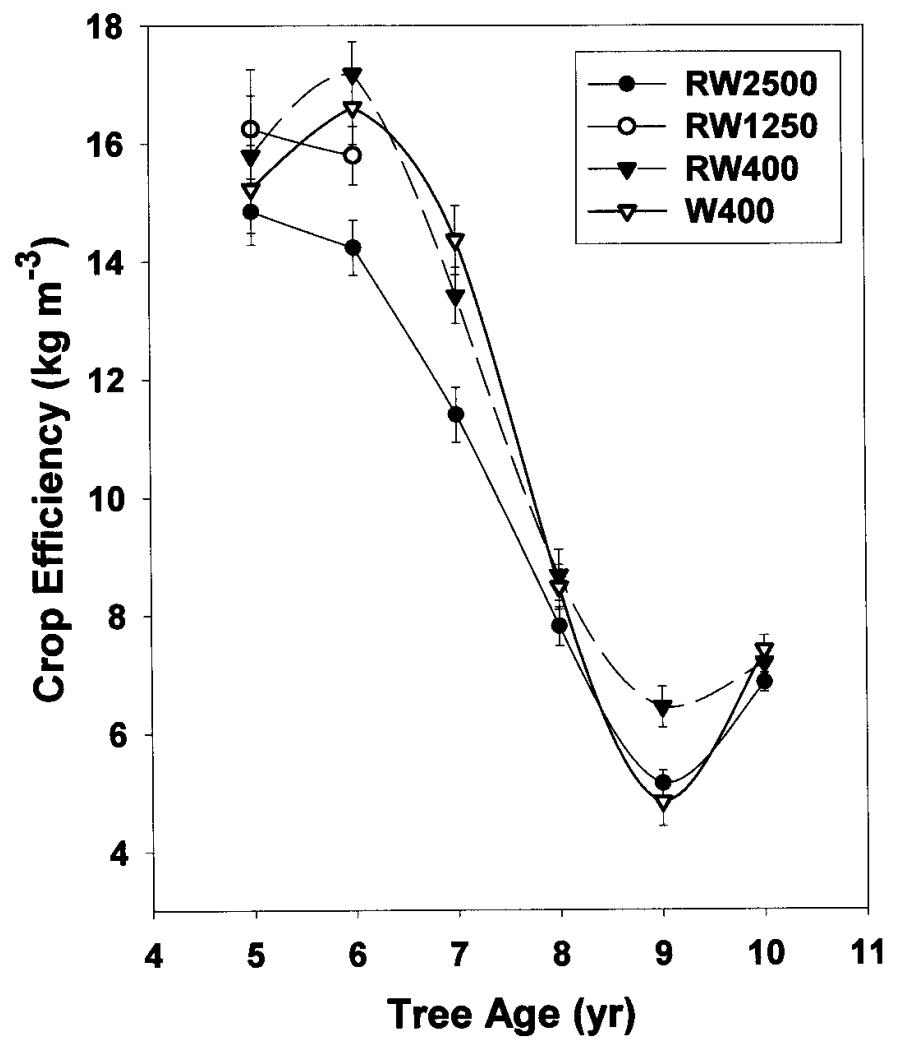

Fig. 5. Crop efficiency in kg fruit produced per cubic meter of canopy volume. Data are averaged over both scions and all rootstocks, mean, and standard error.

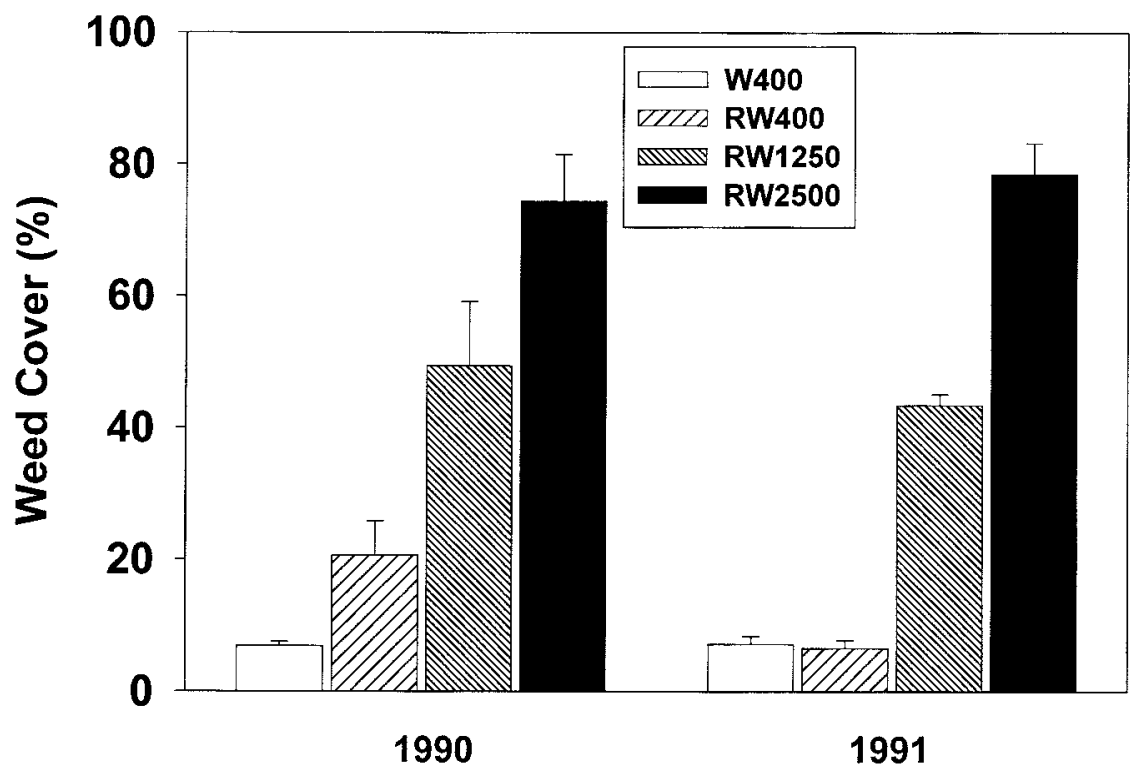

Fig. 6. Irrigation rate effects on percent weed cover in 2 years. tion with treated sewage effluent. SpringerVerlag, Berlin.

Koo, R.C.J. and M. Zekri. 1989. Citrus irrigation with reclaimed municipal wastewater. Proc. Fla. State Hort. Soc. 102:51-56.

Lapena, L., M. Cerezo, P. Garcia-Augustin, and I. Morell. 1996. Wastewater irrigation of citrus trees. Proc. Intl. Soc. Citricult. 808-812.

McMahon, B.R., R.C.J. Koo, and H.W. Persons. 1989. Citrus irrigation with reclaimed wastewater. Trans. Citrus Eng. Conf. 35:1-17.

Maurer, M.A. and F.S. Davies. 1993. Microsprinkler irrigation of young 'Redblush' grapefruit trees using reclaimed water. HortScience 28:1157-1161.

Maurer, M.A., F.S. Davies, and D.A. Graetz. 1995. Reclaimed wastewater irrigation and fertilization of mature 'Redblush' grapefruit trees on spodosols in Florida. J. Amer. Soc. Hort. Sci. 120:394-402.

Menocal-Barberena, O.A. 1999. Citrus fibrous root distribution as affected by rootstock and irrigation rates of reclaimed water. MS Thesis. Horticulture Dept., Univ. of Florida, Gainesville.

Neilsen, G.H., D.S. Stevenson, J.J. Fitzpatrick, and C.H. Brownlee. 1989. Nutrition and yield of young apple trees irrigated with municipal waste water. J. Amer. Soc. Hort. Sci. 114:377-383.

Parsons, L.R., T.A. Wheaton, and P. Cross. 1995. Reclaimed municipal water for citrus irrigation in Florida, p. 262-268. In: F.R. Lamm (ed.). Microirrigation for a changing world. Proc. Fifth Intl. Microirr. Congr. Amer. Soc. Agr. Eng.

Parsons, L.R. and T.A. Wheaton. 1996. Florida citrus irrigation with municipal reclaimed water. Proc. Intl. Soc. Citricult. 692-695.

Pettygrove, G.S. and T. Asano, Eds. 1985. Irrigation with reclaimed municipal wastewater-a guidance manual. Lewis Publ., Chelsea, Mich.

Tucker, D.P.H., A.K. Alva, L.K. Jackson, and T.A. Wheaton (eds.). 1995. Nutrition of Florida citrus trees. Univ. of Florida Coop. Ext. Serv. SP169.

Wheaton, T.A. and I. Stewart. 1973. Optimum temperature and ethylene concentrations for postharvest development of carotenoid pigments in citrus. J. Amer. Soc. Hort. Sci. 98:337-340.

Wheaton, T.A., J.D. Whitney, W.S. Castle, R.P. Muraro, H.W. Browning, and D.P.H. Tucker. 1995. Citrus scion and rootstock, topping height, and tree spacing affect tree size, yield, fruit quality, and economic return. J. Amer. Soc. Hort. Sci. 120:861-870.

Zekri, M. and R.C.J. Koo. 1993. A reclaimed water citrus irrigation project. Proc. Fla. State Hort. Soc. 106:30-35. 